DIGITAL COMMONS
@ UNIVERSITY OF SOUTH FLORIDA

Volume 7

Issue 1 Volume 7.1 (Spring 2017)

\section{ABO: Interactive Journal for Women in the Arts, 1640-1830}

2017

\title{
Charlotte Charke's Gun: Queering Material Culture and Gender Performance
}

Jade Higa

University of Hawaii, Manoa, jadehiga@hawaii.edu

Follow this and additional works at: https://digitalcommons.usf.edu/abo

Part of the Feminist, Gender, and Sexuality Studies Commons, Literature in English, British Isles Commons, and the Theatre and Performance Studies Commons

\section{Recommended Citation}

Higa, Jade (2017) "Charlotte Charke's Gun: Queering Material Culture and Gender Performance," ABO: Interactive Journal for Women in the Arts, 1640-1830: Vol.7: Iss.1, Article 2.

http://doi.org/10.5038/2157-7129.7.1.1153

Available at: https://digitalcommons.usf.edu/abo/vol7/iss1/2

This Scholarship is brought to you for free and open access by Digital Commons @ University of South Florida. It has been accepted for inclusion in ABO: Interactive Journal for Women in the Arts, 1640-1830 by an authorized administrator of Digital Commons @ University of South Florida. For more information, please contact digitalcommons@usf.edu. 


\title{
Charlotte Charke's Gun: Queering Material Culture and Gender Performance
}

\author{
Abstract \\ This essay juxtaposes readings of material culture and gender performance in Charlotte Charke's \\ Narrative of the Life of Mrs. Charlotte Charke (1755). It argues that the transient relationship Charke has \\ to the objects in her life mirrors the fluidity of her gender. The essay ultimately uses Charke's narrative as \\ a case study in a questioning of a binarized gender matrix. The thesis suggest that, though we lack \\ language to fully describe it, characters and historical figures like Charke move beyond and explode \\ gender binaries. \\ Keywords \\ Charlotte Charke, Gender performance, Queer, Material culture, Sexuality studies, Eighteenth-century \\ Creative Commons License \\ (c) (i) $\odot$ \\ This work is licensed under a Creative Commons Attribution-No Derivative Works 3.0 License.

\section{Cover Page Footnote} \\ The author would like to thank Laura Engel, who read innumerable drafts of this work and who first \\ encouraged me to read Charke's memoir in graduate school. She would also like to thank the Aphra Behn \\ Society--a most engaging and encouraging group of scholars.
}




\section{Charlotte Charke's Gun: Queering Material Culture and Gender Performance}

At the age of fourteen, Charlotte Charke spent a considerable amount of time alone with her gun. She brought birds home for dinner and enjoyed fantasies of herself as "the best Fowler or Marksman in the Universe" (Charke 16). Although her mother eventually took the gun away and set Charke to more "gentlewoman[ly]" tasks (16), the young adventurer continued to use objects to negotiate her gender identity. Throughout her autobiography, The Narrative of the Life of Mrs. Charlotte Charke, Charke implements both male and female clothing along with a wide variety of objects - including a fiddle, a sword, torches, oils, sugar, pens, puppets, and wigsto signal and manipulate her social position and her gender performance. Like a skilled comedienne with innumerable props, Charke uses clothing and material culture to distinguish her fluctuating character. While readers are aware that the narrator throughout the text is consistently Charlotte Charke, we see her take on the roles of Physician, Gardner, Stable Boy, Shopkeeper, Puppeteer, Baker, Female Actress, and Male Actor through acquiring the necessary clothing and objects that signify a particular profession and/or gender. The fluctuation and adaptability that Charke's body represents enable her to obtain and subsequently cause her to lose a wide variety of material goods. This process of moving around, among, and with material objects is indicative of Charke's gender fluidity. This essay will examine how the material goods that move in and out of Charke's life indicate what I call the seams of her performance.

Though I am not arguing for a transgender reading of Charke in this essay, Judith J. Jack Halberstam's ideas from "Transgender Butch" are a useful caution for many queer reading practices and provide a foundation for my methodology. Halberstam writes of transgender discourse: it "in no way necessarily argues that people should just pick up new genders and eliminate old ones or proliferate genders at will because gendering is available as a self-determining practice" (478). Similarly, my essay is by no means arguing that Charke uses objects to change her gender whenever a whim strikes her. Rather, this essay reads Charke's Narrative as a depiction of a kind of amateur spelunking; she moves through the dark spaces of gender and embodiment with little direction and no certainty. Her nonmale and/or nonfemale genders are "in circulation" and "under construction" (478). Subsequently, this essay describes Charke's body as "fluid" because she resides in the liminal spaces of gender and embodiment. Like a spelunker must attach her rope to the rock before she descends down a vertical cave, Charke uses objects as tools to anchor her performance in gender normativity before she descends into the darkness of unpredictable gender fluidity. Yet she, as we will see, consistently detaches herself from these anchors and allows herself to free fall further and deeper into the unknowns of gender. As we follow her into the earth, we discover that the 
objects are simply indications of her performance. When she disentangles herself from those anchors to gender norms, it is the frightful fall - the uncontrollable descent into the unknown - that help us identify the seams in her performance; the objects are merely points of access where we can discover what she is not. It is Charke's uninhibited plunge into the cave that reveals our own lack of terminology and our need to further explore gender fluidity.

This essay contributes to the critical study of Charke as gender bender through a close examination of the material culture in Charke's autobiography. Although many critics have identified important objects in her life (such as her father's periwig, her male clothes, and her puppets), few have drawn connections between Charke's gender performance and the material culture she owns, handles, and writes about. It is the examination of the objects in Charke's life that further reveals the fluidity of her self-representation and her gender. In the last thirty years, Charke has become an icon in gender studies and queer theory. ${ }^{i}$ But in contemporary sexuality studies, critics struggle with the "knotty intertwining of identities" (Nussbaum 228) of Charke's Narrative. As critics attempt to place her somewhere between "hetero" and "homo," they sometimes lose sight of her specific importance in eighteenth-century gender studies. Many often simply use the term "queer," or they argue that Charke embodies unnamed new categories of gender and sexuality because theoretical scholarship lacks the language to explain her sexual subject position. ${ }^{\text {ii }}$ Through this essay, I wish to encourage eighteenth-century sexuality studies to move away from definitive labels and categories of sexual identity. Instead of attempting to use our labels as a means to dress historical figures in ill-fitting costumes, we can push eighteenth-century sexuality studies forward through an examination of the seams of those costumes-considering what is holding those identity labels together and how they can be continuously ripped apart and rejoined in new and interesting ways.

\section{Prosthetic phalluses, female pens, and gender fluidity}

Charlotte Charke makes clear to her audience that she is aware of her own gender performance and introduces herself by provoking her audience to question her gender. In the first pages of A Narrative of the Life of Mrs. Charlotte Charke, Charke introduces her readers to the "little Brat of [her] Brain" by petitioning for their patience. She asks that readers give her book the "common Chance of a Criminal, at least to be properly examin'd, before it is condemn'd" (7), and the readers' perception of her gender appears to be the root of this uncertainty over the quality of her text. Her first line reads, "As the following History is the Product of a Female Pen, I tremble for the terrible Hazard it must run in venturing into the World, as it may very possibly suffer, in many Opinions, without perusing it" (7). The apprehensiveness Charke expresses over her Narrative being "the Product of a 
Female Pen" reveals both her knowledge of and anxiety over an ambiguous gender performance. She worries that the public will form negative opinions of her Narrative without actually reading it because they believe a female writer is likely to produce "Nonsense and Inconsistencies" (7). But to have a female pen is to have a phallic symbol with a feminine descriptor; Charke is grappling with her own physical traits of one gender and a signifier of another. Ironically, the opening of her Narrative foreshadows how much her text will produce what she fears: "Inconsistencies." These inconsistencies in her own gender performance-those moments, for example, when readers cannot be certain if she is dressed as a man or woman-are indicative of her gender fluidity as they reveal the seams in her performance.

A key to understanding Charke's gender fluidity is hidden in the inconsistencies where she encompasses multiple genders through phallic symbols. Charke uses these gendered objects as oppositional points of consideration. The objects' shape is an indication of their association with the assumed biology of gender norms; however, the objects themselves are become less important than how she uses them. For example, she uses a broom ${ }^{\mathrm{iii}}$ to help her acquire the necessary clothing when, at the age of four, she plays dress up and pretends to be her father (the playwright and theater manager Colley Cibber):

By the Help of a long Broom, I took down a Waistcoat of my Brother's, and an enormous bushy Tie-wig of my Father's, which entirely enclos'd my Head and Body, with the Knots of the Ties thumping my little Heels as I march'd along, with slow and solemn Pace. The Covert of Hair in which I was conceal'd, with the Weight of a monstrous Belt and large Silver-hilted Sword, that I could scarce drag along, was a vast Impediment in my Procession. (10)

This scene of preparation before she performs as Cibber is full of conflicting gender signifiers as well as an apparent uncertainty about whether or not she needs a phallus to complete her gender performance. The long broom, as a phallic signifier, enables Charke to obtain the masculine clothing. She is able to reach her father's wig and her brother's clothes because the broom extends her reach. The broom acts as Charke's prosthetic phallus, which she needs in order to reach her ultimate goal: those sartorial gender signifiers. Once she reaches the clothes and wig, she can leave the broom aside. She no longer needs that particular symbol of masculinity in order to embody a gender. However, she also immediately takes up a "large Silver-hilted Sword" - another potential prosthetic - that drags along the ground because it does not fit her body. The function of both the broom and the sword is important. The broom, her first prosthetic, is taken up by necessity to enter into the 
performance of her desired gender; the sword, her second prosthetic, is taken up by choice. Once she has used the broom to acquire clothes and wig, she is able to cast the phallus aside and has the option to adopt another prosthetic or to walk away from all phallic substitutes. Her desire to carry the sword becomes a "vast Impediment in [her] Procession"; she would be more mobile without it. Yet, she wants the sword so that she can complete her performance. The broom and the sword emphasize the fluidity in her performance - her ability to readily pick up and put aside a phallic symbol - as well as the awkwardness of a gender binary. Charke struggles to sit between masculine and feminine; instead, as a child, she feels the need to embody masculinity fully with a phallic symbol, even if it hinders her progress.

The awkwardness exists because of the gender binary-because she as performer and we as observers try to find her place within the matrix of masculinity and femininity. Yet, as Judith Butler argues in Undoing Gender, this binary is damaging and restrictive to gender and sexuality studies:

To assume that gender always and exclusively means the matrix of the "masculine" and "feminine" is precisely to miss the critical point that the production of that coherent binary is contingent, that it comes at a cost, and that those permutations of gender which do not fit the binary are as much as part of gender as its most normative instance. (42)

The term gender fluidity "suggest[s]," as Butler notes, "that gender has a way of moving beyond that naturalized binary" of masculine and feminine (42-43). And it is Charke's use of objects, such as the broom and the sword, which emphasize this fluid movement "beyond" binarized gender. Looking more closely at this gender fluidity, at the seams of her gender performance, yields insight into what gender beyond binaries could look like.

\section{Wigs and the seams of performance}

Scholars agree that the wig Charke describes herself wearing as a child is similar to the famously giant periwig that Cibber wore as part of his character, Sir Novelty Fashion (Powell and Roach 79). ${ }^{\text {iv }}$ The magnificence of this wig is indisputable, and it emphasizes the fluidity in her earliest performances of gender. ${ }^{v}$ Kristina Straub argues that the parodic nature of little Charlotte's cross-dressing highlights the ambiguity of sex and the constructed nature of gender: through "mimicry," Charke "gestures toward the artificiality — and tenuousness — of the masculinity that she, in turn, puts on" (140). By describing the process of putting on the wig, Charke invites her readers to see the seams of her performance. She shows us how she can slip 
into and out of a role through the use of objects. The wig, like the broom and the sword, enables us to identify those transitions or seams of performance. Just as a costume change reveals the unnaturalness, the awkwardness, the imperfection of performance, those are the moments in which we discover the fluid nature of Charke's gender; those are the moments that break down binaries.

Charke's wig emerges again when, in an often-studied incident, Charke runs out into the street carrying her ill child, Kitty, and the crowd mistakes her for a young father because she is wearing men's clothing. ${ }^{\text {vi }}$ These men's clothes shown in tandem with her maternity brings together the two polarities of the false gender binary and engages with a variety of gender possibilities. What happens, according to her autobiography, is this: Charke leaves her home to pawn some clothing and returns to find her daughter on the floor in "strong Convulsion Fits" (51). She then picks up Kitty, drops her, and runs into the streets (without her daughter), screaming because she thinks Kitty is dead. During all of this, she is wearing men's clothing. As Charke mourns loudly in the street, she obtains an audience:

I run into the Street, with my Shirt-Sleeves dangling loose about my Hands, my Wig standing on End . . . And proclaiming the sudden Death of my much-beloved Child, a Crowd soon gathered round me, and, in the Violence of my Distraction, instead of administring any necessary Help, wildly stood among the Mob to recount the dreadful Disaster. (52)

Charke is disheveled and her "Wig" is "standing on End." Once she draws in the audience, her "Distraction" becomes too great to remember her daughter. In the following paragraph, she goes on to speculate how her impromptu audience might have felt about her performance: "it drew them into Astonishment, to see the Figure of a young Gentleman, so extravagantly grieved for the Loss of a Child" (52). Although the passage begins with an image of her as a distressed mother, Charke quickly shifts into the role of performer. ${ }^{\text {vii }}$ The shift indicates that while the crowd may not be necessary to Charke's gender performance, she does seek out an audience and revels in the attention. The audience she describes and the readers of her Narrative both see her disheveled wig and loose shirtsleeves, but the readers are privy to Charke's post-scene reflection where she speculates on what the audience must have been thinking.

Charke's shift from grieving mother to grieving father materializes when the audience arrives, and this highlights her ability to slip into and out of roles, particularly when she is working with objects. Joseph Roach argues, "performers frequently use hairstyle as a marker of their mastery of their preassigned or coveted roles" (127). Charke's wig in this scene is a marker of her genders, her emotions, 
and her performance as a father. She laughs at the audience she has fooled and she invites her readers to laugh with her. This scene also shows us a moment of a time when she was for the most part living and working as a man. In this story, she exposes a tiny bit of her reality; it is enough to hint at the performative nature of her shifting gender markers. She is here presenting herself as a handsome man and a grieving father. She is also, through her narrative voice and her "female pen," presenting herself as a witty author and a skilled actress. She does not in this moment say, "I wish I were a man," nor does she say, "Of course, I wasn't a man." All that happens in relation to gender identification is inferred through material objects. Thus, she invites the audience to do that inference - to take part in active reading and interpretation - and to pay attention to her performance. The wig signifies Charke's existence within the space beyond the false gender binary. As a representation of the seams in her performance, the wig emphasizes the moment of transition. Yet - be it her gun, her wig, or her pen-Charke's transient relationship to things enables her to navigate the circumference of her body. Rather than settle on the side of a binary, she moves beyond gender binaries. For Charke, material culture is a means through which she can both access and express gender fluidity.

\section{Decoding sartorial signifiers: Beyond a binarized gender matrix}

In addition to the variety of material objects that appear in Charke's Narrative, the clothing she wears (or does not wear) provides an entry point into an examination of her gender fluidity. Although clothes certainly serve as gender signifiers in Charke's cross-dressing, for her they are also valuable objects that she struggles to maintain and retain. Her lack of attachment to clothing - male or female - further highlights her ability to move fluidly through gender by readily picking up and putting down sartorial gender signifiers. Charke is constantly changing her clothes. At times, she does so to signify a change in her profession, but she mostly changes her outfit out of necessity. She borrows clothes that she does not have or sells clothes for something she needs more. For Charke, clothes are objects that she uses to manipulate or improve upon her circumstances. Clothes can be used to fool people about her social status or to get money-either through selling the clothes themselves or using the clothes she has in her acting jobs. ${ }^{\text {vii }}$ Charke's Narrative confronts the conventional representations of women and their clothing through her own body. She is able to use clothing to bend her gender, sex, social status, and identity; in taking up a variety of differently gendered clothing as readily as she puts it down, her body becomes a manifestation of gender fluidity.

Charke dressed in breeches regularly both on and off stage until 1753, just a few years before her death in 1760. Being an eighteenth-century woman in men's clothing is by no means unique to Charke. Susannah Centlivre, Sally Paul, Mary Hamilton (the inspiration for Fielding's The Female Husband), and Hannah Snell 
of The Female Soldier all dressed and lived for a time as men. Yet Charke's Narrative reveals that, unlike these other women, she does not have a focused purpose for dressing as a man (such as freedom of movement, financial necessity, or even nonnormative sexual desire). Charke embodies a multiplicity of genders with no clear purpose or goal. In fact, she refuses to tell her readers why she dresses as a man. ${ }^{\text {ix }}$ She teases her readers with indications that she does have a reason (or multiple reasons) for cross-dressing, but she then says that she cannot reveal the reason to us:

My being in Breeches was alledged to me as a very great Error, but the original Motive proceeded from a particular Cause; and I rather chuse to undergo the worst Imputation that can be laid on me on that Account, than unravel the Secret, which is an Appendix to one I am bound, as I before hinted, by all the Vows of Truth and Honour everlastingly to conceal. (73)

Also: "My going into Mens Cloaths, in which I continued many Years; the Reason of which I beg to be excused, as it concerns no Mortal now living, but myself" (141). She suggests that cross-dressing served a specific purpose in her life, but that purpose is an extremely delicate secret that, if revealed, might unearth someone else's secret and that it is no concern of ours. Her last mention of it ("as it concerns no Mortal . . . but myself") reads a little like "it is none of your business." Even though she opens up her entire life to an audience through her Narrative, this particular lack of transparency highlights how carefully she controls what she discloses about her life. It emphasizes, through the inconsistencies in her performance, that her "tell all" memoir is sewn together with a particular pattern in mind. Most critics recognize Charke's self-awareness; establishing her conscious participation in crafting her own image identifies her as an agent in selecting the roles she plays. ${ }^{\mathrm{x}}$ As readers, we are hyper aware of the way Charke presents her various selves because she often shows us the performative shifts she makes, particularly through material objects and clothing. ${ }^{\mathrm{xi}}$ Yet it is her refusal to allow audiences to assign her a gender that also enables us to see the carefully constructed image of her as constant performer. As a result, it is not always clear when Charke is being sincere; or, perhaps the conclusion we can come to is that she is never truly sincere - particularly when she discusses her own gender performance. Charke's Narrative frustrates our natural desire to delineate the difference between performance and reality. This mirrors the awkwardness one can feel when confronted with genders that move beyond the binarized matrix. Charke, through her contradictory candidness and secrets, forces us to confront our own lack of language to describe what we struggle to understand. Her gender performances are neither definitively male nor definitively female, and we cannot argue that she 
moves back and forth between polarities if she is constantly residing between or beyond them.

The story Charke tells in her Narrative comprises scenes of drag, performance, adventure, and scandal. Through the examination of the material objects in Charke's life, we can begin to appreciate the fluid gender performance that this puzzling autobiography embraces. Because Charke does not commit to a specific gender role, critics often struggle with this lack of clarity and with her inconsistencies. She takes down a broom only to pick up a sword; with a "female pen" she describes her performance as a grieving father. The first story Charke tells about her beloved gun and the mother who took it away serves as an allegory for our own reliance on labels. Charke fantasized about the many possibilities that particular object could open to her; many of her fantasies were not founded in observable reality, but her childhood innocence allowed her imagination to embrace what adults saw as impossibilities. Her mother forces Charke into a feminine box, but through her Narrative Charke tears apart the metaphorical dress she was required to wear as a child. She celebrates inconsistencies and she encourages her audience to see the seams in her performance that move beyond signifiers of masculinity and femininity. Charlotte Charke deepens our understanding of gender fluidity even as she frustrates it. Although we may not have developed the language to identify Charke's gender(s) yet, her Narrative invigorates us to accept and begin to fathom genders that move away from, play with, undo, and explode the masculine/feminine binary. 


\section{Notes}

${ }^{\mathrm{i}}$ In her afterward to the seminal collection of essays Introducing Charlotte Charke, edited by Phillip Baruth, Felicity Nussbaum writes, "Charke's subjectivity is less a monolith, a reified and knowable self, than a knotty intertwining of identities that yield multiple and often contradictory material effects that are as varied and heterodox as the roles she performed in public and private" (228).

${ }^{i i}$ For example, in "Charlotte Charke and the Liminality of Bi-Genderings: A Study of Her Canonical Works," Polly S. Fields argues that Charke "creates a new gender system, through the adoption of a series of dualities" in the characters of her work (225). Fields claims that through her drama, fiction, and autobiography Charke creates "another Eden" in which Adam (or masculinity) and Eve (or femininity) reside in one body (227); Charke's intention is to extract herself from the oppressive rules of a heteronormative matrix. While Fields' analysis of the variety of Charke's gender performances produces fascinating insights, I take small issue with the article's conclusion. Charke is clearly attempting to break away from the heteronormative social regulations of gender (that man must be masculine and woman must be feminine); however, by arguing that Charke takes both genders into her own body through the adoption of a series of "dualities," Fields unintentionally iterates the discourse of a false gender binary. The word duality, when applied to a gender system, implies that there are only two gendered subject positions that Charke can embody. While Charke's ability to oscillate between genders contributes to a disruption of the heteronormative matrix, arguing that Charke occupies only two gendered subject positions ultimately places her back in the tension between the two polarities. The result of this argument is an iteration of discourse that reinforces a binarized view of gender. iii I should note here that the broom is traditionally associated with domestic labor, and a reading that explores the multiple gender associations of objects in Charke's narrative would be fascinating. For the purposes of my argument, I have restricted my readings of objects' gender to their shape - as they are associated with normative biology. This reading cannot address all the complexities of gender that this passage invites us to explore, but I hope they will all be acknowledged as we continue to do our own amateur spelunking into the depths of Charke's writing. ${ }^{\text {iv }}$ Cibber's wig took on a life of its own in tandem with his celebrity; it was so large that it "entered the stage on its own sedan chair, borne by two lackeys, following in Sir Novelty's train, like plunder in Triumph" (Powell and Roach 80). ${ }^{v}$ For scholars who write about Charke's performative life, the wig and attention she gets for it represents the "heady allure of celebrity, the gratification of 
attracting an audience and making them laugh" (Shevelow 53). Kristina Straub points out that "by Charke's time, the full-bottomed periwig was considered oldfashioned, and actors who continued to wear them were considered ridiculous. Charke's 'fondness' for a periwig read in this context more like a parodic comment on father's earlier professional pose as Lord Foppington [or Sir Novelty Fashion] than like a serious desire to emulate her father" (140).

${ }^{\text {vi }}$ Kathryn Shevelow identifies the peculiarity of the scene's description: "Instead of securing help from the crowd, Charlotte enacted a scene of maternal anguish worthy of Agnes or Andromache-with one difference: her men's clothes" (286). vii Shevelow points out that because the crowd that gathered around Charke were unknown to her, this incident with Kitty and the crowd's reaction to it "provides an indication of how [Charke] appeared to strangers on the street: that is, to most people she encountered in London. They interpreted Charlotte according to her dress - which, even in its disordered state, signified that she was a man" (286). viii In Women, Work, and Clothes in the Eighteenth-Century Novel, Chloe Wigston Smith reexamines the function of clothes in fiction. She challenges the argument that clothes are mere representations of the character wearing them and establishes that "in fiction [clothes] could be reworked and reshaped for a new and more progressive vision of womanhood founded on usefulness and pragmatism" (17). Smith also notes that although her book focuses on the novel, her "investigations into other cultural forms convey how fiction exposed representations of women that trivialized and constrained their clothes and labor by subscribing to familiar customs and conventions surrounding the body, identity, dress, and gender" (11).

${ }^{\text {ix }}$ Some argue that Charke is transgender and that is what motivates her to crossdress. For excellent readings of Charke as transgender, see Marilyn Morris, Jason Cromwell, and Liberty Smith.

${ }^{x}$ Cheryl Wanko argues that Charke's Narrative is "a complex interplay between roles imposed and roles assumed, contributing to a fragmented gender performance." Wanko explains that Charke writes from the point of view of an actress standing on stage: "The actress assumed the qualities that fit the dramatic role her audience expects ... the actress herself is always aware that she is creating an illusion of self" (87).

${ }^{x i}$ Christine Cloud argues that this representation of multiple selves is evidence for potentially identifying Charke as transvestite. In "The Chameleon, Cross-Dressed Autobiography of Charlotte Charke (1713-1760)," Cloud suggests, "The transvestite autobiography introduces variable multiple selves which are oftentimes in opposition to one another. These selves refuse the regulation of their body through their clothing, thus they undermine the universal 'I's' attempt to define itself as a spiritual essence which is in opposition to an 'Other' which has been essentialized as body. They then base their autobiographical portrait of 
themselves on their refusal to allow society to sign them a particular gender and then order them to act in complete correspondence with the sex-based role that they have been assigned to play for their entire lives" (870). Cloud goes on to use Charke's Narrative as a case study in her broader theories about transvestite autobiographies.

\section{Works Cited}

Butler, Judith. Undoing Gender. Routledge, 2004.

Charke, Charlotte. A Narrative of the Life of Mrs. Charlotte Charke. 1755. Edited by Robert Rehder, Pickering and Chatto, 1999.

Cloud, Christine. "The Chameleon, Cross-Dressed Autobiography of Charlotte Charke (1713-1760)." Women's Studies, vol. 38, no. 1, Dec. 2009, pp. 857-71. Academic Search Elite, doi:10.1080/00497870903238448. Accessed 16 Feb. 2017.

Cromwell, Jason. "A Female-to-Male Transgendered Perspective." Two-Spirit People: Native American Gender Identity, Sexuality, and Spirituality, edited by Sue-Ellen Jacobs, et al., U of Illinois P, 1997, pp. 119-42.

Fields, Polly S. "Charlotte Charke and the Liminality of Bi-Genderings: A Study of Her Canonical Works." Pilgrimage for Love: Essays in Early Modern Literature in Honor of Josephine A. Roberts, edited by Sigrid King, Medieval and Renaissance Texts and Studies, 1999, pp. 21-48.

Halberstam, Judith J. Jack. "Transgender Butch: Butch/FTM Border Wars and the Masculine Continuum." The Routledge Queer Studies Reader, edited by Donald E. Hall and Annamarie Jagose, Routledge, 2013, pp. 464-87.

Morris, Marilyn. "Objects of Desire, Identity, and Eros in the Writings of Lord Hervey and Charlotte Charke." Sexual Perversions, 1670-1890, edited by Julie Peakman, Palgrave Macmillan, 2009, pp. 72-94.

Nussbaum, Felicity. "Charke's 'Variety of Wretchedness." Introducing Charlotte Charke: Actress, Author, Enigma, edited by Philip E. Baruth, U of Illinois P, 1998, pp. 227-43.

Powell, Margaret K., and Joseph Roach. "Big Hair." Eighteenth Century Studies, vol. 38, no. 1, 2004, pp. 79-99. Project MUSE, doi:10.1353/ecs.2004.0062. Accessed 16 Feb. 2017.

Roach, Joseph. It. U of Michigan P, 2007.

Shevelow, Kathryn. Charlotte: Being a True Account of an Actress' Flamboyant Adventures in Eighteenth-Century London's Wild and Wicked Theatrical World. Picador, 2005.

Smith, Chloe Wigston. Women, Work, and Clothes in the Eighteenth-Century Novel. Cambridge U P, 2013. 
Smith, Liberty. 'Listening to the 'Wives' of the 'Female Husbands': A Project of Femme Historiography in Eighteenth-Century Britain." Journal of Lesbian Studies, vol. 6, no. 2, 2002, pp. 105-20.

Straub, Kristina. Sexual Suspects: Eighteenth-Century Players and Sexual Ideology. Princeton UP, 1992.

Wanko, Cheryl. "The Eighteenth-Century Actress and the Construction of Gender: Lavina Fenton and Charlotte Charke." Roles of Authority: Thespian Biography and Celebrity in Eighteenth-Century Britain, Texas Tech UP, 2003, pp. 71-89. 